\title{
An Examination of Meaning in Life, Satisfaction with Life, Self-Concept and Locus of Control among Teachers*
}

\author{
İbrahim Taş ${ }^{1}$, Murat İskender ${ }^{2}$ \\ ${ }^{1}$ Bulent Ecevit University, Zonguldak, Turkey \\ ${ }^{2}$ Sakarya University, Sakarya, Turkey \\ Correspondence: İbrahim Taş, Department of Educational Sciences, Bulent Ecevit University, Turkey, 67300 Kdz Ereğli, \\ Zonguldak, Turkey.
}

Received: November 7, 2017

doi:10.11114/jets.v6i1.2773
Accepted: November 26, $2017 \quad$ Online Published: November 28, 2017

URL: https://doi.org/10.11114/jets.v6i1.2773

\begin{abstract}
The aim of this study is to examine meaning in life, satisfaction with life, self-concept and locus of control among teachers by several variables. The research group was composed of 363 teachers (114 [40\%] women, 219 [60\%] men) working in several districts of İstanbul. The data were collected with Meaning in Life Scale (MLS), Satisfaction with Life Scale (SWLS), Social Comparison Scale (SCS), and Rotter's Locus of Control Scale (RLCS). Pearson's Correlation Analysis, Independent Samples T-Test and Mann Whitney-U and Kruskal-Wallis H test were utilized. A positive relationship was found between experienced meaning in life and satisfaction with life and self-concept while a negative relationship was found between experienced meaning in life and locus of control. Expected meaning in life, satisfaction with life and locus of control were found to differ by gender. It was also determined that expected meaning in life and self-concept differed by marital status.
\end{abstract}

Keywords: Meaning in life, satisfaction with life, locus of control, self-concept

\section{Introduction}

\subsection{Meaning in Life}

Despite being addressed in diverse ways, concept of meaning refers to individuals' life being coherent, important, and under control (manageable) and to a possessive feeling towards life (Schnell, 2009). In other words, meaning can be thought as well-being of individual in his/her life (Steger, Oishi \& Kashdan, 2009) or a more extensive component of well-being (Ryff and Singer, 1998). Concept of meaning in life denotes how individuals regard their lives as being significant and meaningful; their effort or desire to have a purpose in life and shape and reinforce that purpose (Steger, Kashdan, Sullivan \& Lorentz, 2008). Meaning in life refers to the value and purpose of life, important goals, and mostly, spirituality (Jim, Purnell, Richardson, Golden-Kreutz, \& Andersen, 2006). According to Leontiev (2005) meaning is an outcome of coherence. He argues that an event occurs once it logically coheres with individuals' previous beliefs and expectations.

Concept of meaning in life was first addressed in the works of Spranger, Dilthey, Freud and Adler and then in the works of Frankl and Leontiev (Leontiev, 2005). Concept of meaning in life as a clinic construct emerged for the first time when V. Frankl (1946) used the concept at Nazi Concentration Camps in therapeutic procedures. Frankl defined meaning as a reason for living and trying to comprehend how important life is by experiencing or feeling it. Frankl (1946) argued that life does not lose its meaning no matter what conditions human is in, and meaning does not only cover happy experiences but also suffering and deprivation. According to him, life does not have a single meaning. Everyone is meant to find their own meaning.

In the literature, the concept of the meaning of life is covered under two headings. The concept of the meaning sought and the concept of the meaning experienced. With the concept of the meaning sought, it is meant that there is no meaning and no purpose in the life of the individual, and that the individual is in search of meaning and purpose. With the concept of meaning experienced, it is meant that the individual finds his/her life meaningful and knows

${ }^{*}$ This article is derived from the postgraduate thesis. 
what would make his/her life meaningful. Furthermore, with the concept of the meaning experienced, it is understood that there is a clear purpose in the life of the individual (Steger, Frazier, Oishi \& Kaler, 2006).

It is seen that there is limited number of studies on meaning in life. It was found in the studies that there is a negative relationship between the subscale of expected meaning in life and self-alienation (Akın \& Taş, 2011) and a positive relationship between expected meaning in life and authentic life, social values, spirituality, honor, freedom, futuwwa, career values, and intellectual values (Baş 2014). It was seen in another study that experienced meaning in life significantly differs by internal motivation, external motivation, and job satisfaction (Bektaş, 2012). It is also observed that spirituality, futuwwa and materialistic values (Baş, 2014) predict the subscale of experienced meaning in life. Experienced meaning in life also differ by the variables of marital status and gender (Bektaş, 2012) and being a woman and whether being married or single predict experienced meaning in life. It is seen that expected meaning in life does not significantly differ by gender and marital status (Bektaş, 2012). Yet, expected meaning in life is predicted by salary and general job satisfaction (Bektaş, 2012), romantic values, spirituality, and freedom (Baş, 2014). Expected meaning in life was also found to be positively related to social, materialistic, intellectual and romantic values, freedom, success and intellectual values and negatively related to spirituality (Baş, 2014). Baş (2014) determined that subscales of meaning in life do not differ by gender. According to existentialist psychologists, meaning increases the quality of life and hope while mitigating the thought of suicide (Mascaro \& Rosen, 2005; Dogra, Basu \& Das, 2011). In other studies, meaning in life was found to be positively related to psychological well-being (De Klerk et al., 2009; Jaarsma, Pool, Ranchor \& Sanderman, 2007), extraversion, adaptability, responsibility, and personal traits and negatively related to neurotic personal traits (Jaarsma et al., 2007). It is understood from the studies that the results regarding the relationship between meaning in life and sociodemographics are contradictory and no relationship was found in most studies (De Klerk et al., 2009).

\subsection{Satisfaction with Life}

Addressing meaning in life as well-being (Steger et al., 2009; Ryff \& Singer, 1998) indicates its relationship with the concept of satisfaction with life. As a concept that can also be defined as how an individual evaluates his/her life as being positive in accordance with his/her own criteria, it is also a cognitive and judgmental process (Diener, Emmons, Larsen \& Griffin, 1985). Satisfaction with life is an outcome achieved by individuals comparing what they have and want to have (Altay \& Avc1, 2009). Positive emotions stemming from the outcome refer to satisfaction with life while negative emotions are about dissatisfaction.

Vast number of studies have been conducted on satisfaction with life in the literature. It was found in a study by Şahin (2008) that the private school teachers who chose the profession willingly and perform social activities had higher levels of satisfaction with life ( Yılmaz \& Şahin, 2009). Another study (Recepoğlu, 2013) determined a positive relationship between satisfaction with life and teaching. It was also found in the study that satisfaction with life significantly differs by gender and female teachers have higher levels of satisfaction with life. It was determined in the study conducted by Telef (2011) that satisfaction with life was found positively related to self-efficacy subscale of student participation and efficacy of using teaching strategies, efficacy of classroom management, and general self-efficacy. A study which investigated problem-solving skills as a predictor of satisfaction with life (Kabasakal \& Uz Baş, 2013) found a negative and significant relationship between problem total score and confidence in problem-solving skills and satisfaction with life. In the study conducted by Gündoğar, Gul, Uskun, Demirci and Keçeci (2007) with university students, the students who had enrolled in the university so that they could have a job at least had lower levels of satisfaction with life than the students who enrolled in the university because they wanted that occupation very much. McCoy and Heritage (1992) found a positive relationship between self-esteem and satisfaction with life. Stein and Heimberg (2004) found the dissatisfaction with life to be positively related to anxiety and major depression in their study.

It is observed in the literature in general that satisfaction with life is not related to gender and marital status (Sahin, 2008; Sahin, 2010; McCoy \& Heritage, 1992; Telef, 2011); variables such as gender, ethnicity and income do not predict satisfaction with life and it is effectively predicted by personal tendencies, close relationships and culture (Myers \& Diener, 1995 in Dingiltepe, 2009).

\subsection{Self-Concept}

The concept of social comparison used by Leon Festinger in 1950s can be defined as individuals forming an opinion about themselves or the process of comparing themselves with others to protect their opinion on themselves (Bilgin, 2003). Comparisons with individuals or groups who are in a better state are upward comparisons, comparisons with unfortunate individuals or groups who are in a worse state are downward comparisons and comparisons with individuals or groups who are in the same state and conditions are parallel comparisons, or counterpart comparisons (Petersen \& Ritz, 2010). According to Festinger, individuals feel the need for evaluating their opinions, abilities, values and convictions to come to a judgment, which is an innate need (Bilgin, 2007). Individual may make comparisons to improve himself/herself beyond this basic need. Especially comparisons made in the specialization areas of others serve this purpose (Suls, Martin \& Wheeler, 2002). 
It is observed in the literature that several studies have been conducted on social comparison/self-concept. Kılıç, Tanrıkulu and Uğur (2013) found in their studies that there is a weak positive relationship between educators' levels of self-concept and job satisfaction. In the study performed by Celik and Odac1 (2011), a negative and significant relationship was found between self-concept and submissive behaviors among preservice teachers and submissive behaviors predict self-concept. It was determined in a study by Yllmaz (2010) that there is a negative relationship between self-concept and psychological symptom levels. Güven (2008) found a positive relationship between self-efficacy beliefs and self-concept among adolescents. Gülbahçe (2007) determined that occupational maturity levels do not differ significantly by self-concept. In the study conducted by Pinargil (2008), a positive relationship was found between social comparison and self-efficacy, social support from family, friend and a special person and self-esteem. It was found in the study conducted by Erözkan (2004) with high school students that there is a negative relationship between social comparison and depression. İskender and Tanrıkulu (2010) explored a positive relationship between social comparison and social support. In the same study, social comparison was found to be negatively related to self-hatred and hatred against others and positively related to anger management. In the study performed by Lindner, Hughes and Fahy (2008), social comparison scores of female university students with eating disorders were found to be higher in female-dominant universities than universities where female and male students are in equal number. Social comparison scores were found to be on the lowest level in male-dominant universities. Sohn (2010) found that women and men had similar upward social comparison scores in terms of body image. Whereas a relationship was found between self-development and upward comparison and counterpart comparison among women, there was a weak relationship between self-development and upward comparison among men.

It is observed in the studies on social comparison that there is no significant relationship between social comparison scores and sociodemographics such as gender, marital status, seniority (Erözkan, 2004; Gulbahçe, 2007; İskender \& Tanrıkulu, 2010; Yılmaz, 2010; Çelik \& Odacı, 2011; Kılıç et al., 2013).

\subsection{Locus of Control}

According to Rotter (1966), concept of locus of control is about individual's belief that he/she has the ability to control events in his/her life. Addressed in two ways as internal and external locus of control, concept of locus of control has different impacts on individual's behaviors. Internally-controlled individuals believe that they are responsible for their own lives and have the power of changing their lives while externally-controlled individuals believe that they can change few things in their lives through their abilities and behaviors. Externally-controlled individuals believe that they are controlled by chance, fate, opportunities or other individuals and events, but internally-controlled individuals believe that they control their behaviors in their lives (as cited in Schultz \& Schultz, 2007).

Several research studies have been conducted on locus of control in the literature. In the study performed by Tümkaya (2000) with primary school students, a positive relationship was found between external locus of control and burnout levels. It was also explored in the study that the women were more externally-controlled than the men. İhtiyaroglu and Demir (2015) found that locus of control does not differ significantly by gender. A strong relationship was found between internal locus of control and teacher effectiveness while external locus of control was found to be weakly related to teacher effectiveness in the study. A negative and significant relationship was found between internal-external locus of control and self-efficacy belief in a study conducted by Çelikkaleli (2010) with adolescents. The study also concluded that academic and emotional self-efficacy is a significant predictor of locus of control. It was observed in a study conducted by Erbaş (2009) that risk-taking levels were higher in the individuals with external locus of control. The study also found that the men had internal locus of control while the girls had external locus of control. Sarı (2007) found that positive beliefs about worry are related significantly and positively related to external locus of control. It was also found in the study that external locus of control is positively and significantly related to intolerance and anxiety. Küçükkaragöz (1998) explored in the study conducted with primary school teachers that the women had higher locus of control scores than the men. It was found that the teachers who regard their jobs as stimulating and motivating were more externally controlled than those who regard their jobs. Buluş (2011) determined that locus of control is positively related to purpose orientation but negatively related to avoidance of purpose orientation among preservice teachers. A positive relationship was also found between locus of control and academic achievement. DeNeve and Cooper (1998) examined the relationship between happiness and locus of control. Accordingly, it was determined that the participants with internal locus of control were happier than the participants with external locus of control. Additionally, Internal locus of control was positively correlated with perfectionism, while external locus of control was negatively correlated with perfectionism (Jackman, Thorsteinsson \& Mcneil, 2017)

Teaching profession is a profession that maintains its reputation in our society. People entrust their children to the teachers. In this context, it can be said that the bases of the future are laid by the teachers. The perspective on life, self concept, life satisfaction level and locus of control of the teachers will all be reflected to the students, as well. In the literature, no study dealing with these concepts regarding the teachers has been encountered. For this reason, such a study to be done in teachers is important. 
Women in our country are actively involved in business life. Unlike men, however, their traditional duties (child care, housework) are also ongoing. This situation can be extremely tiring for women. For this reason, it is important to focus on gender variable to learn the thoughts of women about these concepts (meaning of life, life satisfaction, self concept and locus of control) in the study.

\section{Method}

\subsection{Research Questions}

The research sought for answers to the following questions:

1. Is there a significant relationship between experienced meaning in life, expected meaning in life, satisfaction with life, social comparison and internal/external locus of control among teachers?

2. Do experienced meaning in life, expected meaning in life, satisfaction with life, social comparison and internal/external locus of control differ by gender among teachers?

3. Do experienced meaning in life, expected meaning in life, satisfaction with life, social comparison and internal/external locus of control differ by marital status among teachers?

\subsection{Research Model}

The study aims to examine the relationship between teachers' meaning in life, satisfaction with life, internal/external locus of control and social comparisons by certain variables. The study was conducted in the relational survey model. This is a model that aims to identify the change between two or more variables and the degree of the change in question (Karasar, 2012).

\subsection{Study Group}

363 teachers working in several districts of İstanbul who were randomly chose participated in the research. $144(40 \%)$ of the participants are women while $219(60 \%)$ of them are men. As for the marital status of the participants, $206(57 \%)$ of them were married, $143(39 \%)$ were single, and $14(4 \%)$ were divorced.

\subsection{Data Collection Instruments}

The data used in the research were collected with Meaning in Life Scale (MLS), Satisfaction with Life Scale (SWLS), Social Comparison Scale (SCS), and Rotter's Locus of Control Scale (RLCS). A personal information form was also used to identify teachers' demographics.

\subsubsection{Personal Information Form}

The personal information form was prepared by the researcher to receive participant teachers' sociodemographics.

\subsubsection{Meaning in Life Scale}

The Meaning in Life Scale was used to assess the meaning in life in the research. The scale was developed by Steger et al., (2006) and adapted into Turkish language by Akın and Taş (2011). MLS is a 7-point Likert-type assessment tool with 10 items. It is composed of two subscales: experienced meaning in life and expected meaning in life. Scale's factor loads vary between .54 and .77 while its item-total correlation scores vary between .42 and .68 . It was found in the confirmatory factor analysis of the two-dimension scale that the scale provides good fit $\left(x^{2}=77.77, \operatorname{sd}=31\right.$, $\mathrm{RMSEA}=.065, \mathrm{NFI}=.95, \mathrm{CFI}=.97, \mathrm{GFI}=.96, \mathrm{AGFI}=.93, \mathrm{RFI}=.93, \mathrm{SRMR}=.065)$. The internal consistency reliability coefficients of the scale are .77 for experienced meaning and .83 for expected meaning.

\subsubsection{Satisfaction with Life Scale}

Developed by Diener et al., (1985) to investigate satisfaction with life and adapted into Turkish language by Durak, Şenol Durak and Gençöz (2010), the Satisfaction with Life Scale was used in the research. SWLS is a 7-point Likert-type assessment tool which is composed of five items and one factor. Its reliability was evaluated using the internal consistency indexes. Internal consistency coefficient of the Satisfaction with Life Scale is .81 and its corrected item correlations vary between .53 and.65. It is seen that its chi-square value $\left(x^{2}=10.129, \mathrm{df}=2.026, p=.072\right)$ is significant. The fit indexes were found $\mathrm{IFI}=.994, \mathrm{TLI}=.987, \mathrm{CFI}=.994, \mathrm{SRMR}=.020, \mathrm{RMSEA}=.043$. Chi-square multiple correlation was listed between .39 and .50 .

\subsubsection{Social Comparison Scale}

The Social Comparison Scale developed by Şahin, Durak and Şahin (1993) was used to assess self-concept in the research. It is a bipolar, 18-quality scale which is applied to adolescents and adults. Higher scores mean positive self schema while lower scores mean negative self-schema. Cronbach's Alpha value of the scale was found to be .76 and .89 in the reliability studies (Şahin \& Durak, 1993 as cited in Savaşır \& Şahin, 1997). In scale's criterion related validity study, correlation of the Social Comparison Scale with the Beck Depression Inventory was found to be -.19 (p<.000), 
and it was seen that its correlations with the Symptom Checklist subscales vary between 0.14 and -0.34 (Savaşır \& Şahin, 1997, p. 112).

\subsubsection{Rotter's Internal-External Locus of Control Scale}

Rotter's Internal-External Locus of Control Scale was used to assess the locus of control in the research. Developed by Rotter (1966) and adapted into Turkish language by Dağ (1991), this scale is composed of 29 items. The scale provides information on the internal-external nature of individuals' locus of control. Higher scores refer to external locus of control while lower scores mean internal locus of control. Cronbach's Alpha internal consistency coefficient of the scale was found to be .71 . Scale's reliability coefficient was calculated to be .68 with KR-20 technique in a 99-participant sample. In scale's criterion related validity study, a significant correlation $(\mathrm{p}<.001)$ at -.29 was found between Rosenbaum Learned Resourcefulness and internal locus of control. A significant correlation ( $\mathrm{p}<.001)$ at .21 was found between external locus of control and general symptom score of Symptom Checklist (SCL-90-R) (Savaşır \& Şahin, 1997).

\subsection{Data Analysis}

Pearson's Correlation Analysis and Independent Samples T-Test were performed for the analysis of parametric data. Non-normal distribution variables were analyzed with nonparametric tests. To analyze the non-parametric data, Mann Whitney-U Test and Kruskal-Wallis H Test were used. The data were analyzed in SPSS 15.0 software package.

\section{Findings}

\subsection{First Sub-Problem}

Is there a significant relationship between experienced meaning in life, expected meaning in life, satisfaction with life, social comparison and internal/external locus of control among teachers?

The relationship between experienced meaning in life, expected meaning in life, satisfaction with life, social comparison and internal/external locus of control among teachers was analyzed with Pearson's Correlation analysis. The correlation results are shown in Table 1.

Table 1. Findings regarding the inter-variable correlations

\begin{tabular}{|c|c|c|c|c|c|}
\hline Factor & $\begin{array}{l}\text { Experienced } \\
\text { Meaning in Life }\end{array}$ & $\begin{array}{l}\text { Expected } \\
\text { Meaning in Life }\end{array}$ & $\begin{array}{l}\text { Satisfaction with } \\
\text { Life }\end{array}$ & $\begin{array}{l}\text { Social } \\
\text { Comparison }\end{array}$ & $\begin{array}{l}\text { Internal / External } \\
\text { Locus of Control }\end{array}$ \\
\hline $\begin{array}{l}\text { Experienced Meaning in } \\
\text { Life }\end{array}$ & - & & & & \\
\hline $\begin{array}{l}\text { Expected Meaning in } \\
\text { Life }\end{array}$ & -.041 & _ & & & \\
\hline Satisfaction with Life & $.141(* *)$ & -.078 & - & & \\
\hline Social Comparison & $331(* *)$ & .093 & .012 & - & \\
\hline $\begin{array}{l}\text { Internal / External Locus } \\
\text { of Control }\end{array}$ & $-.177(* *)$ & -.097 & -.011 & -.061 & - \\
\hline Mean & 28.90 & 20.98 & 21.65 & 87.50 & 9.74 \\
\hline Standard Deviation & 5.69 & 8.28 & 6.76 & 12.16 & 4.03 \\
\hline
\end{tabular}

$* * \mathrm{p}<.01$

According to Table 1, experienced meaning in life is positively related to satisfaction with life and social comparison while being negatively related to internal-external locus of control. No significant relationships are observed with other variables.

\subsection{Second Sub-Problem}

Do experienced meaning in life, expected meaning in life, satisfaction with life, social comparison and internal/external locus of control differ by gender among teachers?

The results of the analysis performed to see whether experienced meaning in life, expected meaning in life, satisfaction with life, social comparison and internal/external locus of control differ by gender among teachers are presented in Table 2 .

It is understood from Table 2 that there is no significant difference between the male and female teachers by experienced meaning in life and social comparison. On the other hand, levels of expected meaning in life, satisfaction with life and locus of control were found to differ by gender. 
Table 2. Results of T-test regarding the differences between variables by gender

\begin{tabular}{|c|c|c|c|c|c|c|c|}
\hline Variable & Gender & $\mathrm{N}$ & $\bar{X}$ & $\mathrm{Sd}$ & $\mathrm{T}$ & $\mathrm{Sd}$ & $\mathrm{P}$ \\
\hline Experienced Meaning in & Male & 144 & 28.87 & 6.21 & \multirow{2}{*}{.089} & \multirow{2}{*}{361} & \multirow{2}{*}{.929} \\
\hline Life & Female & 219 & 28.92 & 5.34 & & & \\
\hline \multirow{2}{*}{ Expected Meaning in Life } & Male & 144 & 22.30 & 8.19 & \multirow{2}{*}{-2.47} & \multirow{2}{*}{361} & \multirow{2}{*}{.014} \\
\hline & Female & 219 & 20.11 & 8.25 & & & \\
\hline \multirow{2}{*}{ Satisfaction with Life } & Male & 144 & 20.10 & 6.89 & \multirow{2}{*}{-3.58} & \multirow{2}{*}{361} & \multirow{2}{*}{.000} \\
\hline & Female & 219 & 22.66 & 6.50 & & & \\
\hline \multirow{2}{*}{ Social Comparison } & Male & 144 & 86.59 & 12.50 & \multirow{2}{*}{-1.16} & \multirow{2}{*}{361} & \multirow{2}{*}{.248} \\
\hline & Female & 219 & 88.10 & 11.93 & & & \\
\hline \multirow{2}{*}{$\begin{array}{l}\text { Internal / External Locus } \\
\text { of Control }\end{array}$} & Male & 144 & 8.73 & 3.84 & \multirow{2}{*}{-3.97} & \multirow{2}{*}{361} & \multirow{2}{*}{.000} \\
\hline & Female & 219 & 10.41 & 4.01 & & & \\
\hline
\end{tabular}

\subsection{Third Sub-Problem}

Do experienced meaning in life, expected meaning in life, satisfaction with life, social comparison and internal/external locus of control differ by marital status among teachers?

The results of the analysis performed to see whether experienced meaning in life, expected meaning in life, satisfaction with life, social comparison and internal/external locus of control differ by marital status among teachers are presented in Table 3.

Table 3. Results of Kruskal-Wallis $\mathrm{H}$ test regarding the differences between variables by marital status

\begin{tabular}{|c|c|c|c|c|c|c|}
\hline Score & Groups & $\mathrm{N}$ & $\bar{x}_{\text {sira }}$ & $x^{2}$ & $\mathrm{sd}$ & $\mathrm{P}$ \\
\hline & Married & 206 & 193.34 & \multirow{4}{*}{5.681} & \multirow{4}{*}{2} & \multirow{4}{*}{.058} \\
\hline Experienced & Single & 143 & 166.40 & & & \\
\hline Meaning in Life & Divorced/Separated & 14 & 174.39 & & & \\
\hline \multirow{5}{*}{$\begin{array}{l}\text { Expected Meaning } \\
\text { in Life }\end{array}$} & Total & 363 & & & & \\
\hline & Married & 206 & 169.71 & \multirow{4}{*}{8.402} & \multirow{4}{*}{2} & \multirow{4}{*}{.015} \\
\hline & Single & 143 & 201.70 & & & \\
\hline & Divorced/Separated & 14 & 161.71 & & & \\
\hline & Total & 363 & & & & \\
\hline \multirow{4}{*}{$\begin{array}{l}\text { Satisfaction } \\
\text { Life }\end{array}$} & Married & 206 & 186.05 & \multirow{4}{*}{.715} & \multirow{4}{*}{2} & \multirow{4}{*}{.699} \\
\hline & Single & 143 & 176.54 & & & \\
\hline & Divorced/Separated & 14 & 178.14 & & & \\
\hline & Total & 363 & & & & \\
\hline \multirow{4}{*}{ Social Comparison } & Married & 206 & 196.42 & \multirow{4}{*}{9.323} & \multirow{4}{*}{2} & \multirow{4}{*}{.009} \\
\hline & Single & 143 & 164.55 & & & \\
\hline & Divorced/Separated & 14 & 148.04 & & & \\
\hline & Total & 363 & & & & \\
\hline \multirow{4}{*}{$\begin{array}{l}\text { Internal / External } \\
\text { Locus of Control }\end{array}$} & Married & 206 & 171.59 & \multirow{4}{*}{4.756} & \multirow{4}{*}{2} & \multirow{4}{*}{.093} \\
\hline & Single & 143 & 196.19 & & & \\
\hline & Divorced/Separated & 14 & 190.21 & & & \\
\hline & Total & 363 & & & & \\
\hline
\end{tabular}

According to Table 3, levels of experienced meaning in life, satisfaction with life and internal-external locus of control do not differ significantly by marital status. However, it is seen that expected meaning in life and social comparison levels differ by marital status.

\section{Discussion, Conclusion and Recommendations}

This study aims to examine the relationship between experienced meaning in life, expected meaning in life, satisfaction with life, social comparison and internal/external locus of control among teachers and investigate whether these concepts differ significantly by gender and marital status. The study showed that experienced meaning in life is positively related to satisfaction with life and social comparison while being negatively related to internal-external locus of control. It was also observed that levels of expected meaning in life, satisfaction with life and internal-external locus of control differ significantly by gender but levels of experienced meaning in life and social comparison do not. Moreover, levels of expected meaning in life and social comparison differ significantly by marital status but levels of experienced meaning in life, satisfaction with life and internal-external locus of control do not.

The research concluded that there is a positive relationship between experienced meaning in life and satisfaction with life. Although the studies are not many in the literature, this finding coincides with the literature. Steger et al. (2006) found a positive relationship between experienced meaning in life and satisfaction with life. Given that individuals who find their lives meaningful would live the life to its fullest and see their lives as being valuable, important and 
purpose-oriented (Jim et al., 2006) it can be said that this increases satisfaction with life.

A positive relationship was found between experienced meaning in life and social comparison/self-concept. Accordingly, individuals who find their lives meaningful have positive self-concept. No studies examining the relationship between meaning in life and social comparison were observed in the literature. When interpreting social comparison as a way of showing an individual that he/she is not lacking compared to others and even is much more (Bilgin, 1994), it can be thought that this would enhance self-value, consequently helping individual find his/her life meaningful.

A negative relationship was found between experienced meaning in life and internal-external locus of control. Accordingly, individuals who find their lives meaningful are more internally controlled. In the literature, no studies examining the relationship between meaning in life and locus of control were observed. Given that individuals with internal locus of control think that their lives are under their control, it can be said that such individuals would take the control of their lives in their hands, shape and therefore make meaning of their lives.

As for gender which is another finding of the research, participant teachers' levels of expected meaning in life differed by gender and the male teachers had higher levels of expected meaning in life than the female teachers. It is seen that experienced meaning in life did not differ by gender. Contradictory results are observed in the literature. In the study conducted by Bektaş (2012), experienced meaning in life differed by gender and the female participants had higher scores of experienced meaning in life while expected meaning in life did not differ by gender. Steger et al. (2006) and Baş (2014) concluded that none of the meaning in life subscales differed by gender. It is understood from the contradictory results in the literature that meaning in life is often unrelated to sociodemographics (gender, marital status) (De Klerk et al., 2009).

As for the gender variable, it is seen that the participant teachers' levels of satisfaction with life differed significantly by gender. It is seen that the women have higher levels of satisfaction with life than the men. This finding is consistent with some of the studies conducted with teachers and preservice teaches in the literature (Recepoğlu, 2013; Y1lmaz \& Sahin, 2009; Tomrukçu, 2010). Telef (2011), McCoy and Heritage (1992), Özer (2001), Şahin (2010) and Gümüşbaş (2008) concluded that satisfaction with life does not differ by gender. It is seen that there are diverse results regarding satisfaction with life and the gender variable.

As for teachers' levels of social comparison/self-concept in terms of gender, it is seen that their social comparison scores do not differ significantly by gender. This finding is in parallel with the literature. Previous studies (Kılıç et al., 2013; Çelik \& Odac1, 2011; İskender \& Tanrıkulu, 2010; Yılmaz, 2010; Gülbahçe, 2007; Erözkan, 2004; Sohn, 2010) show that social comparison scores do not differ by gender. This can be explained by the idea that being a woman or a man does not have any impact on positive or negative self-concept.

As for teachers' internal-external locus of control, their scores of internal-external locus of control differ significantly by gender. Given that higher scores in the scale means an increase in external locus of control, it is seen that the female teachers are more externally controlled than the male teachers. There are studies (Tümkaya, 2000; Erbaş, 2009; Kücükkaragöz, 1998) in parallel with this finding in the literature. On the other hand, there are some studies (İhtiyaroğlu \& Demir, 2015; Başol \& Türkoğlu, 2009; Durna \& Şentürk, 2012) which showed that locus of control does not differ by gender. Regarding this result of the study, this can be explained by the fact that girls in our country become exposed to external influences due to the suggestion-based style of upbringing.

It is also seen that teachers' levels of experienced meaning in life do not differ by marital status while expected meaning in life levels differ. The reason for this difference was found to be in favor of the singles between the married and single groups. In the literature, Bektaş (2012) found that meaning in life does not differ by marital status. The finding achieved in this study can be explained by the idea that single teachers are yet to settle down in their lives and they are making efforts to that end.

As for teachers' levels of satisfaction with life by marital status, satisfaction with life does not differ significantly by marital status. There are studies (Şahin, 2008; Temiz, 2010; Şahin, 2010; Tomrukçu, 2010) supporting this finding of the study in the literature. However, some studies (Özer, 2001; Eren, 2008) found higher levels of satisfaction with life among married individuals than singles. Given the fact that satisfaction is described as an individuals' general judgments and evaluations of his/her own life (Çivitçi, 2012), satisfaction with life can be deemed independent from marital status.

As for teachers' social comparison levels with life by marital status, it is seen in the study social comparison differs significantly by marital status. This difference seems to be in favor of the married group. The married teachers have higher scores of social comparison/self-concept than the single teachers. No studies addressing the social comparison with marital status were observed in the literature. Considering the fact that married teachers are back on track to organize their lives as they wish, and the result achieved in the study that the teachers who find their lives meaningful have positive self-concepts, it is understandable that married teachers have positive self-concepts. 
As for teachers' levels of internal-external locus of control by marital status, internal-external locus of control does not differ significantly by marital status. This finding is in parallel with some studies (Küçükkaragöz, 1998; Sulu, 2007; Demirtaş, 2006; Canbay, 2007) conducted in the literature. How locus of control does not differ by marital status is reasonable given that this concept is rather about the controllability of outcomes.

The following recommendations are presented to researchers, experts and psychological counselors in accordance with the results of the study:

The concept of meaning in life seems related to the concepts of locus of control, self-concept and satisfaction with life. However, it is seen that limited number of studies has been carried out on the concept of meaning in life. It is thought that studies on meaning in life would contribute to the effort of filling the gap in the literature.

The sample of this research is limited to teachers. Future studies to be conducted with different populations would provide extensive information on the concept of meaning in life.

Individuals' levels of satisfaction with life and self-concept can be increased by helping them find a meaning in their lives through psycho-educational or group psychological counseling programs to be provided by experts specialized in the field.

\section{References}

Akın, A., \& Taş, İ. (2015). Validity and reliability of the Turkish version of the meaning in life questionnaire. Turkish Studies - International Periodical for the Languages, Literature and History of Turkish or Turkic, 10(3), 27-36. https://doi.org/10.7827/TurkishStudies.7860

Altay, B., \& Aydın, A. I. (2009). The relation between the self care strength and life satisfaction of the elderly living in nursing home. Dicle Medical Journal, 36(4), 275-282. Retrieved from http://dergipark.ulakbim.gov.tr/dicletip/article/view/5000104202/5000097324

Baş, V. (2014). The relationship between values and meaning of life in university students (Master's Thesis, University of Necmettin Erbakan, Konya, Turkey). Retrieved from https://tez.yok.gov.tr

Başol, G., \& Türkoğlu, E. (2009). The relationship between the locus of control and thinking styles of teacher candidates. International Journal of Human Sciences, 6(1). 732-757. Retrieved from http://www.insanbilimleri.com

Bektaş, A. (2012). The effects of job satisfaction and motivation levels on the managers' meaning of life. (University of Maltepe, Istanbul, Turkey, Master's Thesis). Retrieved from https://tez.yok.gov.tr.

Bilgin, N. (1994). Identity problem in the intersection of social sciences. İzmir: Ege Publishing.

Bilgin, N. (2003). Social psychology dictionary. İstanbul: Bağlam Publishing.

Bilgin, N. (2007). Identity construction. Ankara: Aşina Books.

Buluş, M. (2011). Goal orientations, locus of control and academic achievement in prospective teachers: an individual differences perspective. Educational Sciences: Theory \& Practice, 11(2), 540-546.

Canbay, S. (2007). The relationship between the locus of control and job satisfaction of the elementary school teachers. (Master's Thesis, University of Dokuz Eylül, İzmir, Turkey). Retrieved from https://tez.yok.gov.tr

Celik, C., \& Odac1, H. (2011). Teacher candidates submissive behaviors as predictors of self-perception. $e$ - Journal of New World Sciences Academy Education Sciences, 6(2), 1388-1396.

Çelikkaleli, Ö. (2010). Examination of relationship between adolescents self efficacy beliefs and depression, self esteem, locus of control, state anger and anger expression styles (Master's Thesis, University of Mersin, Mersin, Turkey). Retrieved from https://tez.yok.gov.tr

Çivitçi, A. (2012). The relationships between global life satisfaction and psychological needs in university students. Ç. $\ddot{U}$. Journal of Social Sciences Institute, 21(2), 321-336.

Dağ, I. (1991). Reliability and validity of Rotter's internal-external control dimension scale for university students. Journal of Psychology, 7(26), 10-16.

De Klerk, J. J., Boshoff, A. B., \& Wyk, R. V. (2009). Measuring meaning in life in South Africa: validation of an instrument developed in the USA. South African Journal of Psychology, 39(3), 314-325. https://doi.org/10.1177/008124630903900306

Demirtaş, Ç. P. (2006). In the primary education the classroom teacher's procedure of coping with stress, the health of psyche and the direction of check point (Master's Thesis, University of Niğde, Niğde, Turkey). Retrieved from https://tez.yok.gov.tr 
DeNeve, K. M., \& Cooper, H. (1998). The happy personality: a meta analysis of 137 personality traits and subjective well-being. Psychological Bulletin, 124(2), 197-229. https://doi.org/10.1037/0033-2909.124.2.197

Diener, E., Emmons, R. A., Larsen, R. J., \& Griffin, S. (1985). The satisfaction with life scale. Journal of Personality Assessment, 49(1), 71-75. https://doi.org/10.1207/s15327752jpa4901_13

Dingiltepe, T. (2009). Adolescents who have single parents family and full family were compared in respect to their life satisfaction and quality of life (Master's Thesis, University of Çukurova, Adana, Turkey). Retrieved from https://tez.yok.gov.tr

Dogra, A. K., Basu, S., \& Das, S. (2011). Impact of meaning in life and reasons for living to hope and suicidal ideation: a study among college students. SIS J. Proj. Psy. \& Ment Health, 18, 89-102.

Durak, M., Senol-Durak, E., \& Gönçöz, T. (2010). Psychometrik properties of the satisfiction with life scale among turkish university students, correctional officers and elderly adults. Social Indicators Research, 99(3), 413-429. https://doi.org/10.1007/s11205-010-9589-4

Durna, U., \& Şentürk, F. K. (2012). A study to determine the locus of control of university students with the contribution of different variables. ZKÜ Journal of Social Sciences, 8(15), 37-48.

Erbaş, N. (2009). The effect of belief about locus of control of high school seniors on risk-taking behavior (Master's Thesis, University of Sakarya, Sakarya, Turkey). Retrieved from https://tez.yok.gov.tr

Eren, T. A. (2008). Job and life satisfaction level of oncology nurses (Master's Thesis, University of Marmara, İstanbul, Turkey). Retrieved from https://tez.yok.gov.tr

Erözkan, A. (2004). Examination of social comparison and depression levels of high school students according to some variables. Muğla University Journal of Social Sciences Institute, 13, 1-18.

Frankl, V. E. (2009). Man's search for meaning. İstanbul: Okuyan Us Publications.

Gülbahçe, A. (2007). The analysis of self image and social comparison of the students who have different career maturity levels (Doctoral Dissertation, University of Atatürk, Erzurum, Turkey). Retrieved from https://tez.yok.gov.tr

Gümüşbaş, B. (2008). Effects of stress management training program on the students stress management and life satisfaction of elementary school students from 6 to 8 th grades (Master's Thesis, University of Dokuz Eylül, İzmir, Turkey). Retrieved from https://tez.yok.gov.tr

Gündoğar, D., Gül, S. S., Uskun, E., Demirci, S., \& Keçeci, D. (2007). Examining the factors that effect life satisfaction in university students. Clinical Psychiatry, 10, 14-27.

Güven, E. D. (2008). The investigation of self-efficacy beliefs of working adolescents' attending apprentice training program in the base of identity, social comparison, orientation and related demographics (Master's Thesis, University of Pamukkale, Denizli, Turkey). Retrieved from https://tez.yok.gov.tr

İhtiyaroğlu, N., \& Demir, E. (2015). Analysis of the level of teacher effectiveness, having different locus of control. Pamukkale University Journal of Social Sciences Institute, 21, 45-55. https://doi.org/10.5505/pausbed.2015.58815

İskender, M., \& Tanrıkulu, T. (2010). Social support, social comparison, and anger. International Journal of Human Sciences [Online], 7(1), 899-910.

Jaarsma, T. A., Pool, G., Ranchor, A. V., \& Sanderman, R. (2007). The concept and measurement of meaning in life in dutch cancer patients. Psycho-Oncology, 16, 241-248. https://doi.org/10.1002/pon.1056

Jackman, L. C., Thorsteinsson, E. B., \& McNeil, D. G. (2017). Perfect imperfections: Locus of control, perfectionism, and postpartum depression. SAGE Open, 1-8. https://doi.org/10.1177/2158244017710689

Jim, H. S., Purnell, C. Q., Richardson, S. A., Golden-Kreutz, D., \& Andersen, B. L. (2006). Measuring meaning in life following cancer. Quality of Life Research, 15, 1355-1371. https://doi.org/10.1007/s11136-006-0028-6

Kabasakal, Z., \& Uz Baş, A. (2013). Problem solving skills of teacher candidates predicting of life satisfaction. Journal of Research in Education and Teaching, 2(1), 27-35.

Karasar, N. (2012). Scientific research method. Ankara: Nobel.

Kılıç, S., Tanrıkulu, T., \& Uğur, H. (2013). Investigation of job satisfaction and social comparison levels of teachers working in public schools. International Journal of Human Sciences, 10(1), 760-779.

Küçïkkaragöz, H. (1998). Elementary schools teachers locus of control and theirs locus of controls effects on their students (Master's Thesis, University of Dokuz Eylül, İzmir, Turkey). Retrieved from https://tez.yok.gov.tr 
Leontiev, D. A. (2005). Three facets of meaning. Journal of Russian And East European Psychology, 43(6), 45-72.

Lindner, D., Hughes, A., \& Fahy, R. (2008). Eating pathology and social comparison in college females. North American Journal of Psychology, 10(3), 445-462.

Mascaro, N., \& Rosen, D. H. (2005). Existential meaning's role in the enhancement of hope and prevention of depressive symptoms. Journal of Personality, 73(4), 1467-1494. https://doi.org/10.1111/j.1467-6494.2005.00336.x

McCoy, D. M., \& Heritage, J. G. (1992). The relationship of dominance, self-esteem and life satisfaction to selected variables. Retrieved from http://files.eric.ed.gov/fulltext/ED391136.pdf

Özer, M. (2001). To examine the self-care power and life satisfaction of elderly people living in nursing home and family environment (Master's Thesis, University of Ege, İzmir, Turkey). Retrieved from https://tez.yok.gov.tr

Petersen, S., \& Ritz, T. (2010). Dependency of illness evaluation on the social comparison context: findings with implicit measures of affective evaluation of asthma. British Journal of Health Psychology, 15, 401-416. https://doi.org/10.1348/135910709X466676

Pinargil, N. B. (2008). Social comparison in disadvantageous groups, An investigation of social comparison processes and social orientation in hemodialysis patients (Master's Thesis, University of Ege, İzmir, Turkey). Retrieved from https://tez.yok.gov.tr

Recepoğlu, E. (2013). Analyzing the Relationship between Prospective Teachers' Life Satisfaction and Attitudes Concerning Teaching Profession. H. U. Journal of Education, 1, 311-326.

Ryff, C. D., \& Singer, B. (1998). The contours of positive human health. Psychological Inquiry, 9, 1-28. https://doi.org/10.1207/s15327965pli0901_1

Şahin, E. (2010). Creativity, Professional burnout and life satisfaction of primary school teacher (Master's Thesis, University of Sakatya, Sakarya, Turkey). Retrieved from https://tez.yok.gov.tr

Şahin, N. H., Durak, A., \& Sahin, N. (1993). Social Comparison Scale: Evaluation in Cognitive-Behavioral Therapies. Turkish Psychological Association Publications: Ankara.

Şahin, S. (2008). Levels of burnout and life satisfaction physical education teachers (Master's Thesis, University of Mersin, Mersin, Turkey). Retrieved from https://tez.yok.gov.tr

Sar1, S. (2007). The investigation of intolerance of uncertainty, beliefs about worry and locus of control as predictors of trait anxiety (Master's Thesis University of Hacettepe, Ankara, Turkey). Retrieved from https://tez.yok.gov.tr

Savaşır, I., \& Şahin, N. H. (1997). Assessment in cognitive behavioral therapies: commonly used scales. Turkish Psychological Association Publications: Ankara.

Schnell, T. (2009). The sources of meaning in life questionnaire (some): relations to demographics and well-being. The Journal of Positive Psychology, 4(6), 483-499. https://doi.org/10.1080/17439760903271074

Schultz, D. P., \& Schultz, S. E. (2007). History of modern psychology. İstanbul: Kaknüs Psikoloji Yayınları.

Sohn, S. H. (2010). Sex differences in social comparison and comparison motives in body image process. North American Journal of Psychology, 12(3), 481-500.

Steger, M. F., Frazier, P., Oishi, S., \& Kaler, M. (2006). The Meaning in life questionnaire: assessing the presence of and search for meaning in life. Journal of Counselling Psychology, 53(1). 80-93.

https://doi.org/10.1037/0022-0167.53.1.80

Steger, M. F., Kashdan, T. B., Sullivan, B. A., \& Lorentz, D. (2008). Understanding the search for meaning in life: personality, cognitive style, and the dynamic between seeking and experiencing meaning. Journal of Personality, 76(2), 199-228. https://doi.org/10.1111/j.1467-6494.2007.00484.x

Steger, M., F., Oishi, S., \& Kashdan, T., B. (2009). Meaning in life across the life span: levels and correlates of meaning in life from emerging adulthood to older adulthood. The Journal of Positive Psychology, 4(1), 43-52. https://doi.org/10.1080/17439760802303127

Stein, M. B., \& Heimberg, B. G. (2004). Well-Being and life satisfaction in generalized anxiety disorder: comparison to major depressive disorder in a community sample. Journal of Affective Disorders, 79, 161-166. https://doi.org/10.1016/S0165-0327(02)00457-3

Suls, J., Martin, R., \& Wheeler, L. (2002). Social comparison: why, with whom and with what effect? Current Directions in Psychological Science, 11, 159-163. https://doi.org/10.1111/1467-8721.00191

Sulu, H. (2007). The investigation of the relation between the job satisfaction of the teachers work in private and state 
primary schools and the control focus (Master Thesis, University of İstanbul, İstanbul, Turkey). Retrieved from https://tez.yok.gov.tr

Telef, B. B. (2011). The Study of Teachers' Self-Efficacy, Job Satisfaction, Life Satisfaction and Burnout. Elementary Education Online, 10(1), 91-108.

Temiz, K. (2010). Investigation of psychiatric symptoms, life satisfaction, and ways of coping in the blind (Master's Thesis, University of İnönü, Malatya, Turkey). Retrieved from https://tez.yok.gov.tr

Tomrukçu, C. (2010). Life and work satisfaction levels of teachers in public and private primary schools (Master's Thesis, University of Ondokuz Mayıs, Samsun, Turkey). Retrieved from https://tez.yok.gov.tr

Tümkaya, S. (2000). Locus of control in primary school teachers and relationship with consumerism. PAÜ Journal of Educational Faculty, 8. Retrieved from http://pauegitimdergi.pau.edu.tr/Articles

Yılmaz, E., \& Sahin, M. (2009). A study into life satısfaction levels of the teachers workıng at primary education in terms of some variables. e-Journal of New World Sciences Academy, 4(4), 1404-1414.

Yilmaz, F. (2010). The correlation between the social comparison and psychological symptoms in secondary education students (Master’s Thesis, University of Sakarya, Sakarya, Turkey). Retrieved from https://tez.yok.gov.tr

\section{Copyrights}

Copyright for this article is retained by the author(s), with first publication rights granted to the journal.

This is an open-access article distributed under the terms and conditions of the Creative Commons Attribution license which permits unrestricted use, distribution, and reproduction in any medium, provided the original work is properly cited. 